\title{
A Controversial Existence: Chinese Pastoral Feminism
}

\author{
Jinke Li \\ London School of Economics and Political Science, Gender Institute, London.UK. \\ summer.brenda@qq.com
}

\begin{abstract}
After a century of profound historical change, Chinese feminism has developed into diverse schools and branches, with different theoretical approaches and strategies appearing in the internet era. "Chinese pastoral feminism" is a representative and influential form of feminism, but its existence is surrounded by controversy and criticism. It is no exaggeration to state that the very term "Chinese pastoral feminism" has become a thinly-veiled insult, often used ironically to attack some feminist actions or discourses. The debating wars occasioned by Chinese pastoral feminism often appear on China's social media. However, so far, this controversial and influential Chinese feminist phenomenon has not been studied by Chinese academics, and this dissertation will be the first micro-study of the phenomenon of Chinese pastoral feminism. It considers the essential factors contributing to its emergence, and its wider impact upon the development of Chinese feminism.
\end{abstract}

Keywords: Chinese pastoral feminism, Chinese feminism, social media.

\section{Introduction}

The dynamics of Chinese feminism's historical development are complex [1] [2]. A number of Chinese scholars believe that China lacks systematic and pure feminisms [3] [4], and some Chinese feminist scholars are suspicious or even hostile towards some feminist theories [5]. The philosophy and theoretical frameworks of Chinese feminism come from the West [6] [7] [8], but the impact of historical factors and government control [2] [9], has contributed to the partial distortion of the original politics of Western feminism [8], and to the abnormal development of Chinese feminism in the face of state pressure. And then, the paper will research a newly occurred feminism--Chinese pastoral feminism to reflect the whole contemporary Chinese feminist situation.

Chinese pastoral feminism does not literally refer to the feminism of Chinese peasant women. In fact, it is an online term, indicating ironic criticism of some Chinese feminists, and people who do not really have feminist ideas and misinterpret Western feminism. Interestingly, Chinese pastoral feminism is a play on the term "Chinese pastoral dog". The Chinese pastoral dog is a breed unique to China, often found in villages, so "Chinese pastoral" is utilised to describe something or somebody rustic, and here, it is used to satirise those who do not understand "real" feminism, but arm themselves with the flag of so-called Western feminism to attack people online, with asserting that men should do everything for women to show the respect for the consciousness of gender equality.

Main academics have divided the history of Chinese feminism into three phases: the movements around 1919 (the May Fourth or New Culture Movement), the Maoist period, and the 1995 Fourth World Conference on Women in Beijing [8]. Based on this general consensus, this article will focus on these three key historical episodes to identify the reasons for the emergence of Chinese pastoral feminism. Finally, the article will compare the historical trajectory of Chinese feminism and Chinese pastoral feminism, to reflect on the development of Chinese feminism.

\section{The History of Modern Chinese Feminism}

\subsection{Tracing the Trajectory of Modern Chinese Feminism}

Throughout modern Chinese history, the women's movement has been an integral component of Chinese social evolution [10], because of China's unique historical background and social environment [2]. Chinese feminism does not emphasise the individual liberation of women themselves, nor directly challenge national, social and male interests, but it can form an alliance with men, and dedicate individual rights and interests to the salvation of the national revolution. The 
Chinese women's liberation movement, which developed in parallel with the social revolution and the class struggle, is very different to the Western feminist movement, as there have been scarce feminist campaigns in China, not like the West [11]. In China, where gender equality is the official national policy, the women's liberation movement has been championed and led by the state, and feminist progress has been achieved through the political implementation of social reforms [12]. In other words, women's emancipation was carried out by the Chinese social revolution and the government, rather than by women themselves.

\subsubsection{Modern Chinese Feminism and the May Fourth Movement}

The rise of Chinese feminism cannot be separated from men's advocacy and their propaganda [13][14]. In the modern period (1840-1919), a group of male reformists and revolutionaries became the promoters of the rise of Chinese feminism and the early women's movement [11]. The early male revolutionaries, scholars and other "bourgeois reformers", in order to address the national crisis, put forward the "launching female" educational idea, since then, women's lives and their educational problems have aroused the concern of intellectuals [4]. Meanwhile, with the spread of bourgeois democratic doctrine, Western feminism began to enter into China [14], such as Herbert and Muller's writings on feminism.

The new ideas of cultural revival and social reform in the May Fourth Movement energised Chinese women's consciousness [2]. During the May Fourth period, male intellectuals published articles to raise the issue of women's liberation. Extensive coverage of these topics can be traced back to the column "Women's Issues" in New Youth magazine (1917). However, the kind of feminism discussed above did not really involve women's consciousness, for various reasons. Firstly, the questions were raised by men and then solved by men, and as such, their methods and strategies were the product of androcentrism; furthermore, women's issues were tied in with the national movement, only constituting a component of the social revolution, rather than a real feminist movement in its own right [15].

\subsubsection{The Maoist Era and the All-China Women's Federation}

In 1949, the new China was established, with the opening of the Maoist era. From 1949 to 1978, although the status and rights of women in the social structure were enhanced by the Constitution of the People's Republic of China, in reality, women's rights and gender issues were off the agenda, due to extreme politicisation, the politicising of private space, and the general curtailment of citizens' rights [13]. During this period, Chinese feminism and its movement were just part of the propaganda of the Communist Party of China (CCP) [8]. Many scholars hold the view that the CCP cannot genuinely emancipate Chinese women [16].

Although, at that time, the Chinese economy had gradually revived, with the reform of agriculture and other industries, the lack of education in the female labour force made the CCP realise the imbalance and potential danger in the economy [2]. Thus, the Chinese government called for women to enter the workforce, and no longer tolerated the constraints of traditional family values. It can be seen that Chinese feminism and women's liberation were not fully realised in the Maoist era, as this was a movement by the CCP, not of women themselves. Besides, the core purpose of liberating women neglects the issue of sex difference; in reality, the CCP wanted women to become like men to work.

The All-China Women's Federation (ACWF) was organised by the government on 24th March 1949, in order to unite all Chinese women's groups. Academic writers have defined the Women's Federation as "state feminism" [2]. By following the direction and advice of the Chinese government, the ACWF has played a special role in Chinese feminism.

One of the most important policies that the ACWF worked with the Chinese government to implement was the marriage law of May 1950. This law guaranteed all Chinese women's marriage rights, enacting that all women were entitled to freedom of choice in the issues of divorce and marriage, as well as prohibiting "polygamy and prostitution" [17]. However superficially, the marriage law and land reform helped Chinese women escape from the traditional family constraints of the clan system and patriarchy respectively; in practice, these reforms utilised women's powers as 
weapons to attack intellectuals, the elites and capitalists [17]. As above, the status of Chinese women did not really change positively. In the Maoist era, the so-called feminist movement and state policies were of little use for the real liberation of women, and the only true function of these reforms was to benefit the class struggle and the national economy [18].

\subsubsection{Economic Reform and the Fourth World Conference on Women (1995)}

The post-Maoist period began at the death of Mao Zedong. It cannot be denied that Mao seemed sympathetic to the issue of feminism [19], but this era was still problematic [20]. Chinese economic reform started in the post-Maoist era. Since 1978, China has opened up and moved to a market economy; under the influence of the new economy and monetary pressure, the socialist promise of gender equality did not continue. No one was willing to protect women's salaries and work opportunities; no one made any effort to help make women's voices heard [13]. Patriarchy was completely victorious, and men used this economic reform to recover their "patriarchal privileges" which were assigned to women in the Maoist era. This complex and negative situation was exacerbated by the following facts: Chinese men did not speak out to help women; and fewer social resources were allocated to women.

The policies for boosting the Chinese economy, on the one hand, were dedicated to the progress of market revival, but also potentially affected women's situation [10][17]. The transition from the planned economy to the open market, resulted in greater inequality between men and women. For example, the gradual decrease of women working in senior positions and unequal work time, uneven distribution of salaries and other forms of workplace inequality, occurred in Harbin during the period of economic reform [21]. Under the pressure of work, women were potentially persuaded to go back to the family and bear the burdens of the roles of "cooks", "wives", and "mothers" again. Feminism's aim had changed from "icon of the workers" to "good socialist housewives" [17].

However, although unequal job opportunities limited women's progress in terms of the issue of independence, many women thought that the market economy promoted individualism, which could provide a more liberal climate for them to develop "feminist subjectivity" [23]. After the collectivist era of Mao, feminist-consciousness started to emerge; women began to pay attention to femininity (like personal appearance) [24]. Although some women went back to the family, women challenged some of the traditional ideas and attempted to establish new family structures [22]. Nevertheless, in some situations, women cannot balance the relationship between family and social roles. In Desiring China, it found Chinese women often have two conflicting attitudes towards being "independent single women" and "respectable wives". It means that, after the economic reforms, there are attitudes of both "being independent women" and "being dependent on their husbands". The strange case of Chinese feminist consciousness might be ascribed to these complex social changes.

From a global feminist perspective, the Fourth World Conference on Women in Beijing can be seen as a historic event in the development of Chinese feminism [25]. But some critics hold the view that the world conference was essentially the Chinese political theatre, whose purpose was to repair China's relationship with the Western world after the Tiananmen incident; there would be unnecessary consequences for the development of Chinese feminism [8]. This view can be supported by an ironic example: in the conference, facing questioning of the One-Child policy from the Western world, the Chinese government that was dedicated to liberating women rejected halting the implementation of this law. Yet, it cannot be denied that the Chinese government decided to allow Chinese feminism to develop NGOs; meanwhile, the government relaxed its control over Chinese feminism [25]. Thus, this global women's conference marked the new character of feminism in China in the twenty-first century.

\subsection{The New Opportunities for Chinese Feminism in Social Media}

With the development of technology, our lives have become inseparable from the internet and social media in the information era. The internet provides space for women to develop themselves in terms of the shaping of female identities and feminist activities [26]. Online feminists also take advantage of the internet to convey their knowledge, and they encourage women all over the world to use this wonderful communication tool to pursue the liberation of women [27]. However, some 
scholars are worried that the internet and complex existences of social media present potential dangers for the development of feminism and for women [28].

The internet and social media pervade Chinese people's everyday life and influence individuals' lives. In the widely-used social media platforms, there are plenty of individuals, feminist NGOs and groups dedicated to offering voices for Chinese women. However, among these feminist phenomena, Chinese pastoral feminism looks very strange, attracting considerable debate online.

\section{Connecting the History of Chinese Feminism and Pastoral Feminism}

\subsection{What Caused the Occurrence of Chinese Pastoral Feminism?}

The second chapter, tracing the historical development of Chinese pastoral feminism, offers some useful insights. The development of Chinese feminism is full of complexity, resulting from China's history and its politics. In fact, the three phases of Chinese feminism's evolution were not led by Chinese women. During the period of the May Fourth Movement, the roots and development of Chinese feminism were advocated and led by Chinese male intellectuals, and the women's movement in this period was used to save China. Thus, Chinese feminism in this period did not really aim at giving voices for women, and Chinese women lacked consciousness. In the New China established by the communist government of Mao Zedong, the emancipation of women served mainly to increase the labour force. Although the ACWF was established in this period, it was actually controlled by the communist party as "state feminism", which cannot represent the real voices of Chinese women. In Deng Xiaoping's period, the situation was different. In the market economy, women were thought "troublesome", and women were expected to return to the home. However, during this time, Chinese women started to acquire their own feminist consciousness, and a stronger sense of individual desire.

In light of the above, the occurrence of the idea of Chinese pastoral feminism suppressing men might not be unreasonable. First, Chinese feminism does not really appear with independence. Throughout the three stages of Chinese feminist development, the women's movements were not actually led by women themselves and mostly served the national interest, resulting in the abnormal development of Chinese feminist theories and philosophy. Because of this, Chinese pastoral feminism misunderstands real feminism and has extreme ideas. Second, Chinese women in the period of economic reform began to have a sense of women's consciousness. During the former periods of Chinese feminist development, women and men actually had a cooperative relationship and they did not really deal with the core issue - inequality between female and male. However, in the period of economic reform, men tried to seize their job opportunities and social status, which made new women possessing "subjectivity" realise that their situation was not good. Besides, the male society indoctrinated women with traditional female values. These factors contributed to the contradictory values in Chinese women's minds. The researcher thinks the social environment and policies during the economic reform period played an important role in the development of Chinese pastoral feminism, because the economic reforms aroused women's consciousness to fight for their interests, but simultaneously tried to brainwash women with traditional family values - that men should be more powerful than women in the social structure. As a result, pastoral feminism thinks that men should fulfill women's demands, because men have more power than women in terms of physical condition.

\subsection{Reflection on Chinese Feminism}

When many people think Chinese pastoral feminism is a negative term, does it mean that China's feminist development is going backwards? In fact, after tracing the history of Chinese feminism, the researcher thinks that the negative existence of Chinese pastoral feminism does not indicate the regression of Chinese feminism.

The essence of pastoral feminism is that women ask too much from men in terms of interests and status. Although this idea can be radical, it at least implies that women have feminist consciousness - they realise the need to struggle for their rights in an unfair society. Admittedly, the core aim of feminism is to pursue equality between women and men. This purpose entails two key points: women 
possessing self-awareness, and the demand for equality in gender relationships. In essence, Chinese pastoral feminism has these two features, even if its ideology has problems. In the past, Chinese feminism did not contain the fundamentals of feminism in terms of feminist consciousness and challenging men for women's interests. From this point of view, contemporary Chinese feminism has made progress.

On the other hand, it seems that the development of Chinese feminism has encountered obstacles. For example, even though the government agreed to allow feminist NGOs, after two decades, five NGO-feminists were arrested on ridiculous grounds. Also, Chinese pastoral feminism's radical and abnormal feminist goals may unknowingly affect Chinese internet users' minds. In summary, there have been both gains and losses in the developmental path of Chinese feminism.

\section{Conclusion}

In the last century, Chinese women were enlightened and guided by male intellectuals and governments, and joined the path of China's revolution, becoming reformers and workers. With the rise of the market economy, women gradually owning "subjectivity" were repressed in the workplace and pushed back into families. In the contemporary era of information and technology, China's feminism has shown a new character. It interacts with the internet, creating an online feminism, Chinese pastoral feminism.

However, Chinese pastoral feminism triggered many online disputes, and its related topics also attracted great concern, whose influence on the public is unpredictable. Yet, for now, pastoral feminism has led to public suspicion of feminism.

The researcher thinks the appearance of pastoral feminism cannot be an accident: instead, its occurrence was a result of the fact that China has not had real feminism with women's consciousness for a long time, and in particular, the era of economic reform had a contradictory impact on women's minds. Therefore, rather than criticising this phenomenon, reflecting on how it occurred could be preferable. Today, the development of feminism in China has made progress in terms of women's self-consciousness and challenging inequality in gender relationships; yet, the existence of abnormal feminisms, like Chinese pastoral feminism and interference of state control on feminist issues could still push Chinese feminism into a deep developmental quagmire. It seems that the development of Chinese feminism is still a long road.

\section{References}

[1]. Barlow, T. E. (2004). The question of women in Chinese feminism. US: Duke University Press.

[2]. Scroll, E. (2011). Feminism and Socialism in China. Oxon: Routledge.

[3]. Cheng, Mingle \& Zhao, Haiyue. (2015). China's Feminist National Revolutionary Responsibility and Male Characteristics-Also on the Differences between Chinese and Western Feminism. Guangxi Social Sciences, (3), 183-187.

[4]. Goo, X. Q. \& Lin, M. Q. (2010). Analysis on the Contemporary Chinese Female Education from the Perspective of Western Feminist Trend. Journal of Chongqing University of Posts and Telecommunications (Social Science Edition), 22(5), 133-138.

[5]. Yan, Shaping. (2011). The Development of Feminist Theory in China. Theory Research, (14), 55-56.

[6]. Zhang, Hua \& Ren, Yiming. (2008). Chinese Feminist Criticism under the 30-year. Economic Reforms. Journal of Chnagji University, (6), 5-7.

[7]. Shi, Min. (2003). Variations of Western Feminist Ideas [J]. Theory Journal, 110-113.

[8]. Chen, Y. C. (2011). The many dimensions of Chinese feminism. New York: Palgrave Macmillan. 
[9]. Kaufman, Joan. (2012). the Global Women's Movement and Chinese Women's Rights. Journal of Contemporary China, 21(76), 585-602.

[10]. Rolfe, L. (2007). Desiring China: Experiments in neoliberalism, sexuality, and public culture. Duke University Press.

[11]. Xiao, Linda. (2013). Discussing the Male Logic in the Rise of Modern Chinese Feminism. Fujian Tribune: The Humanities \& Social Sciences, (7), 111-114.

[12]. Wang, Fein. (2004). An Unprecedented Trace: 1851-1930, the Development of Chinese Feminist Thoughts and Literatures. Beijing: The Commercial Press.

[13]. Shen, Rue. (2011). Male Feminism: Shu Wu 's Criticism of Chinese Male Dominace. Tribune of Social Sciences, (6), 4-20.

[14]. Wu, Xia. (2012). The Broadcast and Development of Feminist Thought in Modern China. Journal of Chongqing University of Science and Technology, (23), 42-44.

[15]. Zeng, Yanking. (1997). Feminism and Chinese Female Consciousness. Journal of Taizhou University, (1), 16-24).

[16]. Andros, Phyllis. (1983). The Unfinished Liberation of Chinese Women, 1949-1980. Bloomington: Indiana University Press.

[17]. Leung, A. S. (2003). Feminism in Transition: Chinese Culture, Ideology and the Development of the Women's Movement in China. Asia Pacific journal of Management, 20(3), 359-374.

[18]. Gilmanton, C.K. (1994). "Gender. Political Culture, and Women's Mobilisation in the Chinese Nationalist Revolution, 1924-1927." In C.K. Gilmartin, G. Hershatter, L. Rofel, and T White (eds.). Engendering China. Cambridge, MA: Harvard University Press, pp. 195-225.

[19]. Wolf, Margery (1985). Revolution Postponed: Women in Contemporary China. Stanford: Stanford University Press.

[20]. Chen, K. (1995, August 28). Chinese Women Face Barriers on the Job. Asia Wall Street Joumal. Hong Kong.

[21]. Lin, J. (2003). Chinese Women under Economic Reform: Gains and Losses. Harvard Asia Pacific Review, 7(1), 88-90.

[22]. Li, Xiaoping. (1988). Economic Reform and the Awakening of Chinese Women's Collective Unconsciousness. Social Science Front, (4), 300-310.

[23]. Leung, S.M. (1998). Metamorphosis, Stasis and Retro-metamorphosis: Professional Women's Struggle for Transformation in Post-Mao China. Ph.D. Dissertation, University of Lancaster, UK.

[24]. Scroll, E. (1995). Changing Identities of Chinese Women. London: Zed Books.

[25]. Zheng, W. \& Zhang, Y. (2010). Global Concepts, Local Practices: Chinese Feminism Since the Fourth UN Conference on Women. Feminist Studies, 36(1), 40-70.

[26]. Vogt, C. \& Chen, P. (2001). Feminisms and the Internet. Peace Review, 13(3), 371-374.

[27]. Gajjala \& Mamidipudi. (1999). Cyberfeminism, Technology, and International 'Development'. Gender \& Development, 7 (2), 8- 16.

[28]. Mann, L. Kingston. (2014). What Can Feminism Learn from New Media?. Communication and Critical/Cultural Studies, 11(3), 293-297. 